\title{
The Experience of Setting up a New Learning Environment Model in Management Education: Challenges and Frustrations*
}

\author{
Jorge A. Santos, Simone Martins \\ Federal University of Viçosa, Mg, Brazil
}

\begin{abstract}
The aim of this paper is to describe and to reflect on the experience of the authors in setting up a new model of learning environment in management education in a University in Brazil, which was initially called Management Practice Laboratory (MPL). The MPL environment was conceived as a physical and conceptual space where students could learn and practice the principles and techniques of working in organizations in its three levels: operational, tactical, and strategic. The foundations of the project come from social constructivist perspective on learning, from experiential learning literature and from researches that call for a new epistemological ground in management learning. In this paper, the authors will stress some challenges and frustrations with the project since these could be helpful to those interested in similar initiatives. Due to limited space, only two challenges will be stressed: (1) the construction of legitimacy for the project; and (2) the persistent dissonance between theory and practice. The authors conclude that there is room for innovation in the way management is taught and learned in universities since one shows courage to overcome the challenges and frustrations one will certainly deal with.

Keywords: learning environments, management education, simulations, practice laboratory, experiential learning, learning by doing
\end{abstract}

\section{Introduction}

With every mistake we must surely be learning.

(George Harrison)

This paper explores the experience of the authors in setting up a learning environment model in management education at the Department of Management and Accounting in a Federal University in Brazil. The authors had no intention of being only tutors and researchers in the project. Therefore, they immersed themselves in the experience as participant observers, educators, and clients of the experience. They initially called the project Management Practice Laboratory (MPL), although they now perceive the inadequacy of the term: neither management nor laboratory. This will be explained later.

\footnotetext{
* This research was supported by FAPEMIG—-The institution for the development of research in the state of Minas Gerais, Brazil.

Jorge A. Santos, Ph.D., Management Education, Federal University of Viçosa.

Simone Martins, Ph.D. Candidate at CEPEAD/UFMG, Management Education, Federal University of Viçosa.

Correspondence concerning this article should be addressed to Jorge A. Santos, Condomínio Mundial Park, Casa 5, João Brás, 36.570-000, Viçosa, Mg, Brazil. E-mail: jalberto@ufv.br.
} 
The authors define the learning environment as a holistic, physical, and conceptual environment to learn and practise useful skills in the three levels of organisations: the operational, the tactical, and the strategic. They believed that such learning environment would improve students' attitudes not only as professionals, but also personally, as team members and citizens. As it will be made clear throughout the text, their believes are advocated in a passionate way.

The model was conceived—as it will be described—as a two layer environment: (1) at one level, as a physical site, a space; and (2) at another level, as a conceptual framework, which was considered to be a virtual country. As a physical site, the project was understood not only as a facility where students would attend and practise skills, but also as "a product and a precondition of all our practices and engagements... to the construction of the relations between us, and to the blossoming, or not, of identities” (Massey, 2004, p. 1). As a virtual country, the project was understood as a means of structuring meaningful learning situations and the arrangement of andragogic activities (Knowles, 1990). This virtual country was called Simuland. Both layers would be interwoven providing the ambience where a planned micro social environment would take place. These activities would resemble reality, allowing participants to experience work in organisations by planning them, working on their daily routines, and controlling the outcomes. These characteristics are near-but not equal—to some concepts in literature, such as "natural learning” (Armstrong, 2011) and "real-world learning” (Bilimoria, 1998). At the same time, teachers could have the opportunity to conduct in the setting what specialists have called design-based research (Collins, 1992; Barab \& Squire, 2004).

The starting point was a constructivist perspective on learning. From a constructivist perspective, "meaning” was the main construct that students would gain from the learning experience. University students present the six characteristics of adult learners, as advocated by Knowles (1990): (1) They need to know why they are learning before they embark on learning; (2) They need to feel responsible for their own decisions; (3) They have a stock of relevant experiences which they can retrieve; (4) They come to the experience with a readiness to learn; so timing is important to them; (5) They learn best in real-life situations; and (6) They work best through internal motivation not external impositions. The experience was also supported on experiential learning literature (Kolb, 1984), and in the view that learning occurs in communities of practice (Wenger, 1998).

Orchestrating this kind of learning environment, which could flourish in students a large spectrum of working experiences, was the main intention with the project. In this paper, the authors wish to present and to reflect on such experience. The text begins contextualizing management education, especially in Brazil. Afterwards, it reports the authors' dreams - the motivation and the expectations they had with the project. In the next section, it presents how the learning environment was constructed and implemented. The text continues reflecting on the challenges and frustrations the authors faced, and finally, it presents the partial conclusions.

\section{The Context in Management Education}

Before describing under which circumstances the project was conceptualized and operated, it is convenient to frame the context of management education and argue for change. From the outset, the term "management education" should be appropriately defined; it is to mean the whole range of knowledge, skills, and techniques which are necessary to make someone feel comfortable and competent not only in a management position but also working as a clerk or a functional assistant, be it in the finance, in the human resources or any other 
organisational sector. For example, in the MPL, it would be offered opportunities for students to train their technical skills-how to operate office technologies, for instance-and also to develop those conceptual skills which are necessary to conceptualise organisational policies and business plans. Since the two authors were allocated in a department named "management and accounting", the term "management" was used to synthesize this set of "abilities" someone has to achieve to take part in the organisational world. The domain of these abilities is valuable in organisations. Thus, this is what it is expected professional schools offer students.

Demographic changes, economic trends, business expectation, and the increasing demand "from working professionals who need to retool and reinvigorate their carriers" (Global Focus Report, 2008, p. 1) pressure the higher education sector to expand. This is also true in the field of management knowledge and the like. Nonetheless, MCGregor (2004) claimed that:

In a world increasingly characterised by change, diversity and complexity, with educational institutions, like others, aspiring to become "learning organisations" and where the "knowledge economy" is apparently crucial, schools as workplaces for learning appear to remain peculiarly static. The majority exhibit physical, organisational and social arrangements that have changed relatively little in the last 150 years. (p. 13)

In this paper, the authors argue that professional schools need an urgent and radical development in their teaching and learning methodology. That has not been happening unfortunately. Breaking up traditional structures is difficult because it implies the rupture of beliefs so long embraced. Among those, the belief that technical competence acquisition—or worse, the acquisition of technical competence content—is enough and separated from social competence. Therefore, professional schools and universities are well prepared to offer and emphasise retention of content but are barely informed on how to contextualise knowledge.

To change this situation, Schön (1987) advocated the construction of a new epistemology in professional education; one in which pedagogic acts happen in a "reflective practicum":

A practicum is a setting designed for the task of learning a practice. In a context that approximates a practice world, students learn by doing... by undertaking projects that simulate and simplify practice; or they take on real-world projects under close supervision. (Schön, 1987, p. 37)

A "practicum" in management education is not common, but it exists. One acknowledged model is the European practice firm model presented in many countries, including some Asian countries. A practice firm is defined as a "fictitious enterprise with no real goods or money" (Gramlinger, 2003, p. 81). Because of limited space in this paper, this model will not be described. To those interested in understanding how the European practice firm model functions, please check www.europen.de. To a discussion of the pros and cons of the model, see Gramlinger (2003) and to a phenomenographic description of the model see Santos (2008).

\section{The Dream-Our Motivation and Expectation}

The two authors seemed to share the same pedagogical beliefs, for instance, the need for bridging the gap between in-class academic knowledge and practice required by the job market. They argued that, by learning in a simulated environment with close supervision by tutors, students would better envisage how the world of work functions. With students' immersion in the learning environment, they believed in the flourishing of students' implicit knowledge. Concomitantly, they hoped to shorten the distance between tutors and students. The proximity with students during the practicum could help tutors better understand what boosts students learning 
and what would make them become competent professionals and better human beings.

They aimed to do this by adopting a twofold strategy. Firstly, they hoped to give voice to students in class instead of teachers. Teachers would take the role of coachers of meaningful learning experiences or, as Marquardt (2005, p. 142) claimed, "Helping team members to reflect on both what they are learning and how they are solving problems". In doing so, they hoped students would take on the responsibility of their own learning. As a side effect, they also hoped to make them notice how communication affects organisational structure and functioning, in short, how communication constructs reality. Secondly, they hoped students' activities in the model to be as real as possible.

As they shared expectations and ideas, they got more and more enthusiastic about the project and envisaged many other benefits from it. For instance, within the learning environment they hoped to provide training in a large spectrum of information technology - from word processors to spreadsheets to ERPs (Enterprise Resource Planning). Participants would be able to experience different functional areas in a job rotation system. Such experience would allow participants to better understand the need for coordination of work and many of the conflicts originated from there. Another intention was to, within a medium period of time, offer the project to disadvantaged groups in the community, which has been called "social inclusion".

They dreamed of a very stimulating and meaningful learning environment, one in which students would end up with a sense of having experienced "reality". Students' journey through the learning environment would be more intensive and that would lead to a less extensive time within the university. Therefore, this would also benefit the university with an increased rate of efficiency. Moreover, they believed that such learning environment could also be valuable to the department. In addition, they envisaged an opportunity-aside from the benefits for students, department and university—to learn together.

They were also very confident about their proposal because "laboratories" are very common learning environments in all universities, especially in the Natural Sciences courses. They are common in the authors' university as well. The concept is also present in many Social Sciences courses. In the authors' university, for instance, they are present in Law, Communication, and Home Economics courses. Thus, it would not be difficult to explain the intention making an analogy with other campus laboratories. Yet, the authors refused the idea of a laboratory using business games and simulation in the sense proposed in Sauaia's (2008) work.

Due to a shortage of resources, they expected a very tough beginning and foresaw many challenges on the way. Despite that, the trade-off between hard work and satisfaction seemed favourable. With this load of dreams and expectations they started up the project. Simple as that!

\section{Structuring the Project}

Structuring the model was not easy. The first stage was to work on the features and dynamics of the activity. The structure of the activities was based on a conceptual country which was called Simuland. In the project's website, Simuland was defined as "a conceptual country where students... could learn and practice how to conceptualise, construct, operate, and control social organisations”. Since the intention was to mock reality, Simuland would be a conceptual country resembling a real country. The real country would be Brazil. Accordingly to the real country, the conceptual country of Simuland also had its own laws, institutions, government, and procedures. Nevertheless, in Simuland, the complexity of demands real governments exert on 
entrepreneur's shoulders was simplified. Naturally, there were worries about this reduction. However, the intention was to create, in Simuland, an environment in which, beyond learning procedural activities, students could conceive and discuss ideas.

Another step was to write "the laws" of Simuland. In Simuland's Constitution, the rights and duties of citizens were proclaimed. As a means of simplification, article 1 of Simuland's Constitution declared that any unforeseen situation in the virtual country would redirect the resolution to the Brazilian laws. The laws of Simuland were printed off in the official journal of Simuland and also published in the project's website. It was the starting point to show students what would expect from them in the discipline. In other laws of Simuland, the structure and functions of each branch of the government and the rights and duties of citizens and enterprises were stated.

The government of Simuland consisted of a Pedagogical Council and five branches: The Central Bank, The Treasure Department, The Civil and Commercial Department, The Planning and Controlling Department, and The Quality and Productivity Institute. The civil society was represented by students. They would have to constitute social organisations (cooperatives, companies, associations) to produce goods and services to society. Goods and services should be real products, which was an essential difference to models, such as the SENAC model offices and the European/SEBRAE practice firms.

\section{Implementing the Project and Learning From Experience}

Two classes of the project were offered: the first in the second term of 2009, thereafter called class 1 , and the second in the first term of 2010, thereafter called class 2 . The project was offered as a sixty-hour elective discipline, meeting twice a week for two hours each session. There were many difficulties in class 1 . The class consisted of 45 students who divided themselves into five groups constituting the companies of Simuland. The students were from Management, Accounting, and Production Engineering courses. That was more than could be handled. With no adequate space, many activities had to be improvised. Some students had to be allocated in the government because they did not match any group. This was an unexpected, but providential happening, because the government was overloaded with work. There were difficulties in assessing students. Since marking was mandatory in the university and the authors had no previous assessment criteria, they decided to mark students equally. One student contested, suggesting she had committed too much to be equalised with others. Some students failed because they did not show up for the meetings.

In class 2, students were limited to 20. Students attending classes in this semester were from the Management and Accounting courses only. On request, they divided themselves into two companies. Thus, it was much easier. The products or services that the two companies could offer were constrained by creating a list of demands. These demands came from teachers and committees in the department. The authors changed the assessment process, now creating some specific criteria based on company's finance, accounting, and quality performance. With all these arrangements, there was a great improvement.

But still, it all seemed unsatisfactory! There was undoubtedly a large gap between the ideal and the actual situation. For instance, the difficulties of offering a one-term discipline, meeting for a two-hour session, twice a week was soon perceived. In class 1 , having so many students, to make them grasp the meaning of the differentiated learning environment was an impossible mission. Even with the improvements in class 2, the 
achieved outcome was miles away from the authors' requisites.

The government group was a class itself. With 10 students, it was nearly manageable although complicated. As mentioned before, there were lots of things to do and people were available. Nevertheless, the coordination process was difficult, because unlike real organisations, students were available only four hours a week at different times. At an assessment meeting in the end of the term, the group considered that communication and coordination of the government activities were crucial points to enhance the government performance.

\section{Reflecting on the Experience}

Innovative projects are challenging. This would not be different. Bilimoria (1998, p. 267) stated that experiential learning challenges were twofold: pedagogical and institutional. Pedagogical challenges related to questions like:

What is the role of the instructor, and what is the role of the student? What is effective real-world learning and how should it be measured?... How do we ensure that student learning actually occurs in a real-world setting?

Institutional challenges refer to how the innovation will be inserted into the existing educational system. In general, institutions are not prepared to integrate and deal with these perturbing events which disrupt their routine. The questions to be answered here are: "how should institutions train teachers to initiate and structure real-world learning? What technological and other supports do management educators need for effective teaching from a real-world learning perspective and who will provide these?” (Bilimoria, 1998, p. 268). All those questions were pertinent to the project. Nevertheless, in this paper, due to the limited space, just two aspects of the problem are stressed. The first one is considered a challenge and the second one a frustration.

\section{The Construction of Legitimacy for the Project}

The first major challenge of the project was to construct its legitimacy, which would include acknowledgement from both the institution and students. From the institution, it was expected that it would not only grant a license to offer the activity to the students, but also that it would provide the resources and help needed, especially space. Likewise, students were expected to acknowledge the value of the project.

Academics develop esprit de corps. Amdam et al. (2003, p. 18) argued that academic drift-that is, the tendency of faculty "to recruit scholars that contribute to enhance their own reputation"-is one major characteristic of the academic world. It could be also added that academic drift leads to academic rust as well, that is, the tendency of academics to stick to institutionalised procedures in a way that erodes innovation. The general rule seems to be: to be accepted in the corporation one needs to accommodate the innovation to the standard process and, in doing so, it kills the innovation. In the project, the process of erosion began with the very initial approvals, from the explanation of the project to the head of the department and some peers. From the outset, the difficulties were felt. Institutional protocols were asked to be followed, beginning with the submission of a new discipline proposal to the Departmental Board which is responsible for academic decisions and is constituted by all teachers of the department. After approval by the Departmental Board, the proposal followed many other instances before it could be offered to the students. Each of these steps slightly eroded the meaning of the initial proposal. 
Many faculty members initially did not understand the project. They thought it as an interdisciplinary course which could be offered adapting available resources to a different purpose. Even interdisciplinary courses, much simpler in their scope, meet difficulties. Pharr (2000), and Ducoffe, Tromley, and Tucker (2006), for example, described the foundations to a successful interdisciplinary course: "(1) sufficient resources (time, effort, and money); (2) commitment of all constituents; (3) scheduling and other flexibility; and (4) a mission statement, faculty development and hiring practices, and reward systems that support the integrated curriculum” (p. 280). Even with all adequate support, the construction of the legitimacy for a new project may take years to happen.

\section{The Persistent Dissonance Between Theory and Practice}

Simon (1964) and Schön (1983) alerted to the difficulty of integration between theory and practice in professional schools when they were placed into universities. There, professional schools, including management schools, need to sort out the conflict between an academic orientation (management as a discipline) and a practical orientation (management as practice). On the one hand, those who favour the former orientation tend to consider management as science (even when they mention it as applied science). On the other hand, those who favour management as practice tend to consider management as artistry. It follows a series of conflicts, e.g., between analysis vs. synthesis and cause-effect relationships vs. plan of action. Simon (1964) noted that:

The goal of the pure scientist is to explain phenomena in nature: the laws of physics, of physiology, or of consumer behavior... The goal of the practitioner is to devise actions, or processes, or physical structures that work-that serve some specified purpose. (p. 212)

Students detect the conflicts, even unconsciously. Moreover, they are affected by them. In Simuland, the discursive emphasis on practice and the constraints of the real activities were clearly perceived as conflicting by students. Which one was the most important? The discourse or the constrained real-world? This only made students confused and, at the end, the real-world prevailed.

This dissonance between theory and practice was expressed in others forms as well. For instance, that student is captivated by a good traditional lecture or presentation, and that memory has a special role in learning are incontestable. Nevertheless, as Drucker (1984) put it, management is a task, not knowledge. Knowing to recite the phases of the decision-making process does not make anyone to be an effective decision maker. Furthermore, this dissonance is observed among faculty members, for example, when planning teachers do not mind planning their courses or Human Resources teachers do not care about designing, even informally, an assessment plan for their assistants, and so on. What is the implicit learning derived from these lessons?

One author of this paper remembers being at a conference where a senior student from his department asked a friend beside her, after hearing the term "stock" from a consultant. "What is that?" She had to be kidding! Or else, what kind of education is she being offered which cannot even help her to understand a simple conference? But this is reality! Students graduate full of theories about the injustice of social laws; blaming on the tax load taxpayers are subject to; and accusing the misleading information reported by the government on inflation rates. Ask them to run a payment slip, to calculate the tax due in a sale, or to compare the interest of financial transactions, but few of them would do it. Those who defend the traditional learning methodologies would argue that students who have just graduated need only to convey these things, since they are going to be supervisors but not doers. But is it possible to supervise something you do not know how to do? Employers would certainly say "no". 
In sum, the experience was frustrating because those issues were only scratched. Bissel (2004) stated that "teachers whose role conceptions are more complex (i.e., non-traditional) are often unable to fully realize, experience, or implement all desired aspects of their work due to a number of factors”. Clark and Peterson (1986), and Bissel (2004) suggested that, among others, "mandated curriculum materials, resources, time available, habits and student abilities” may inhibit congruence between teachers' state role conception and their actual classroom practices. Most of the time in the MPL was spent with basic questions, such as time schedules, lack of resources, and venue where to allocate students and there were not sufficient attention to go further about the essentials. Despite a general suspicion of the validity of the experience, the real comprehension of its meaning was missing. What was said by students gave the impression that the validity had to do with the newness of the experience and not with its importance. After one and a half year of preparation and implementation, the authors had a clear feeling of dissatisfaction— that was not what had been dreamt of.

\section{Provisional Conclusions}

It is not easy to draw conclusions from an unfinished experience. Therefore, the intentions of this section is to outline some initial considerations about what goes on when one embarks in the stormy waters of experiential learning. These are provisional conclusions not only from a researcher perspective, but also from the multiple perspectives that the authors decided to engage in the project: that of teachers, consumers, government agents, student counsellors, or observers only. That was an interesting, enlarged, fragmented, and frustrating situation of immersion. From this standpoint, these are the provisional conclusions of the experience.

Firstly, the shocking discovery of an "ignorance zone", which is broader than one should imagine. From the experience, it is complicated to say whether students have learned, what made an impact on their future performance, or even if they found the experience meaningful. This immense pool of ignorance sprouted up partially because the MPL was drowned in the midst of two opposed pedagogies: the traditional and the experimental. The traditional methods in management education are comfortable with students' learning achievements, because they rely only on cognitive acquisition, easily measured by the regurgitation of facts by students. The experimental path is messy, non-linear, and unexpected. Whether researchers want to bridge the gap between these two pedagogies, they need to inform practice what is really relevant from what they already have learned from traditional pedagogy. A possible first step in this direction would be to make explicit in management education what Hounsell and Entwistle (2005) named "Threshold Concepts" and the Ways of Thinking and Practising in a Subject (WTPs). By doing that, researchers would inform practice what students need to understand about their professional field.

Secondly, the authors perceived the amazing degree of importance motivation has on students' learning. Not only is the intensity of motivation different, but also the essence of it. Here motivation should not be understood in a traditional way, as a carrot-and-stick approach, but as something coming from inside, a desire to be in, to take part, to throw oneself into the experience. Unlike traditional learning, where one can be a passive listener, experiential learning is only possible with the active participation of the student in the situation.

Thirdly, the authors had to recognize the contradictions between their demands in the project and the formal curriculum students were subjected to in the department. They tried to ignore or, at least, minimize the importance of the "learning milieu" (Parlett, 1977, p. 173), that is, the "features of our education beyond the 
formal realm of the curriculum" and of the "hidden curriculum". The authors acknowledge their failure. The constraints imposed by the institutional rules were silent, but mandatory.

In sum, at least three lessons could be drawn from the experience: (1) the need of support and credibility from the institution where one is steeped to legitimize the project; (2) the inefficacy of mixing experiential learning methods with the traditional learning environment students are accustomed; and (3) the importance of adequate space on the process of education.

Despite these conclusions, be them justifiable or maybe only derived from the authors' inability to overcome the barriers they faced - they argue that a reflective practicum is a precondition to enhance management education. The authors believe, following Mintzberg (2003, p. 377) that management and business schools "have lost their way". Sooner or later, management and business schools should embrace the epistemological shift from the traditional curriculum to a real-world based experience. Grounded on those assumptions, the authors are encouraged to go on developing the MPL project. Nevertheless, there are two essential requirements to do so: (1) an adequate infrastructure to accommodate the innovative purposes of the learning environment; and (2) an explicit support from the relevant institutional instances for the project to be offered.

\section{References}

Amdam, R. P. et al. (Eds.). (2003). Inside the business schools: The content of European business education. Copenhagem: Copenhagen Business Schools Press.

Armstrong, J. S. (2011). Natural learning in higher education. In N. M. Seel (Ed.), Encyclopedia of the Sciences of Learning. Heidelger: Springer.

Barab, S., \& Squire, K. (2004). Design-based research: Putting a stake in the ground. The Journal of the Learning Sciences, 13(1), $1-14$.

Bilimoria, D. (1998, June). The editor's corner: From classroom learning to real-world learning: A diasporic shift in management education. Journal of Management Education, 22(3), 265-268.

Bissel, J. (2004). Teachers' construction of space and place: The method in the madness. Editorial Forum, 46(1). Retrieved December 17, 2010, from http://www.wwwords .co.uk/forum/content/ pdfs/46/issue46_1.asp

Clark, C., \& Peterson, P. (1986). Teachers’ thought processes. In M. Wittrock (Ed.), Handbook of Research on Teaching (3rd ed.). New York: Macmillan.

Collins, A. (1992). Towards a design science of education. In E. Scanlon, \& T. O’Shea (Eds.), New Directions in Educational Technology. New York: Springer-Verlag.

Drucker, P. F. (1984). Introdução à Administração. São Paulo: Pioneira.

Ducoffe, S. J., Tromley, C. L., \& Tucker, M. (2006, April). Interdisciplinary, team-taught, undergraduate business courses: The impact of integration. Journal of Management Education, 30(2), 276-294.

Global Focus Report. (2008). Five global challenges in management education. Retrieved December 17, 2010, from http://www.findarticles.com/p/articles/mi_qa5475/is_200801/?tag=content

Gramlinger, F. (2003). The advantages and disadvantages of learning and teaching in a practice firm. Oxford Studies in Comparative Education, 13(1), 81-90.

Hounsell, D., \& Entwistle, N. (2005). Enhancing teaching-learning environments in undergraduate courses. ETL project—Final report. Retrieved May 1, 2007, from http://www.ed.ac.uk/etl/

Knowles, M. (1990). The adult learner: A neglected species. Houston: TX. Gulf Publishing.

Kolb, D. A. (1984). Experiential learning: Experience as the source of learning and development. Upper Saddle River, N.J.: Prentice Hall.

Marquardt, M. J. (2005). O Poder da Aprendizagem pela Ação: como solucionar problemas e desenvolver líderes em tempo real. Rio de Janeiro: Editora Senac.

Massey, D. (2004). Foreword Forum, 46(1). Retrieved December 17, 2010, from http://www.wwwords.co.uk/forum/content/pdfs/46/issue46_1.asp 
Mcgregor, J. (2004). Editorial Forum, 46(1). Retrieved December 17, 2010, from http://www.wwwords.co.uk/forum/content/pdfs/46/issue46_1.asp

Mintzberg, H. (2003). Managers not MBAs: A hard look at the soft practice of managing and management development. C.A., USA: Berrett-Koehler Publishers.

Parlett, M. (1977). The department as a learning milieu. Studies in Higher Education, 2(2), 173-181.

Pharr, S. W. (2000). Foundational considerations for establishing an integrated business common core curriculum. Journal of Education for Business, 76(1), 20-26.

Santos, J. A. dos. (2008). Students' perceptions of the practice firms network learning environment in Brazil: A phenomenographic approach (Unpublished Ph.D. thesis, University of Lancaster).

Sauaia, A. C. A. (2008). Laboratório de Gestão Empresarial: simulador, jogo de empresas e pesquisa aplicada. Barueri, SP: Manole.

Schön, D. (1983). The reflective practitioner: How professionals think in action. London: Aldershot.

Schön, D. (1987). Educating the reflective practitioner: Toward a new design for teaching and learning in the professions. San Francisco: Jossey-Bass.

Simon, H. A. (1964). The business school: A problem in organizational design. In R. R. Locke (Ed.) (1998), Management Education. England: Dartmouth Publishing.

Wenger, E. (1998). Communities of Practice: Learning, meaning, and identity. Cambridge, U.K.: Cambridge University Press. 